\title{
ROLE OF FERRITE AND PHOSPHORUS PLUS SULPHUR IN THE CRACK SENSITIVITY OF AUTOGENOUSLY WELDED TYPE 309 STAINLESS STEEL
}

F. J. Lambert, Jr

\section{MASTER}

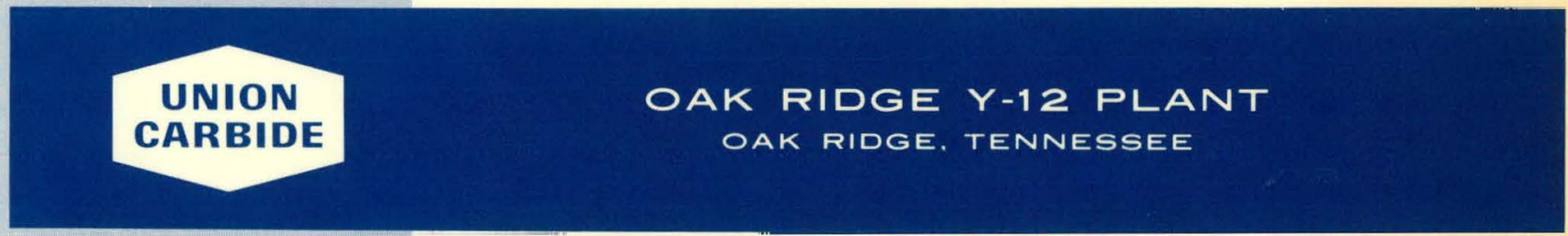

prepared for the U.S. ENERGY RESEARCH AND DEVELOPMENT ADMINISTRATION under U.S. GOVERNMENT Contract W-7405 eng 26 


\section{DISCLAIMER}

This report was prepared as an account of work sponsored by an agency of the United States Government. Neither the United States Government nor any agency Thereof, nor any of their employees, makes any warranty, express or implied, or assumes any legal liability or responsibility for the accuracy, completeness, or usefulness of any information, apparatus, product, or process disclosed, or represents that its use would not infringe privately owned rights. Reference herein to any specific commercial product, process, or service by trade name, trademark, manufacturer, or otherwise does not necessarily constitute or imply its endorsement, recommendation, or favoring by the United States Government or any agency thereof. The views and opinions of authors expressed herein do not necessarily state or reflect those of the United States Government or any agency thereof. 


\section{DISCLAIMER}

Portions of this document may be illegible in electronic image products. Images are produced from the best available original document. 
Reference to a company or product name does not imply approval or recommendation of the product by Union Carbide Corporation or the U.S. Energy Research and Development Administration to the exclusion of others that may meet specifications.

\section{Printed in the United States of America. Available from National Technical Information Service U.S. Department ot Commerre 5285 Port Royal Road, Springfield, Virginia 22161}

Price: Printed Copy $\$ 3.50$; Microfiche $\$ 2.25$

This report was prepared as an account of work sponsored by the United States Government. Neither the United States nor the Energy Research and Development Administration/United States Nuclear Regulatory Commission, nor any of their employees, nor any of their contractors, subcontractors, or their employees, makes any warranty, express or implied, or assumes any legal liability or responsibility for the accuracy, completeness or usefulness of any information, apparatus, product or process disclosed, or represents that its use would not infringe privately owned rights. 
Date of Issue: July 29, 1976

Report Number: Y-2049

Distribution Category: UC-25

\title{
ROLE OF FERRITE AND PHOSPHORUS PLUS SULFUR \\ IN THE CRACK SENSITIVITY OF AUTOGENOUSLY. WELDED TYPE 309 STAINLESS STEEL
}

\author{
F. J. Lambert, Jr \\ Metallurgical Development Department \\ Y-12 Development Division
}

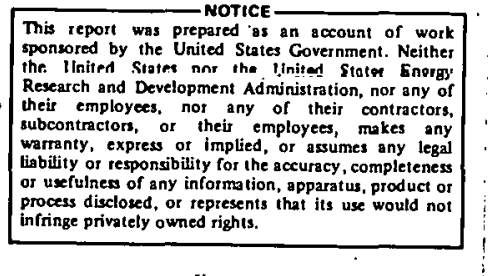

Oak Rldge Y-12 Plant

P. O. Box Y, Oak Ridge, Tennessee 37830

Prepared for the US Energy Research and Development Administration

Under US Government Contract W-7405-eng-26 
A study on autogenous welding of Type 309 thin stainless steel sheet was made after experiencing cracking difficulties on several commercial heats.

A relationship exists between the sum of the phosphorus plus sulfur, the ferrite control of the weld metal, and the crack sensitivity of autogenously made welds. A new simple weld test for thin-gage sheet is utilized for studying the susceptibility to cracking. A chemistry modification is suggested to alleviate possible weld cracking when autogenously welding this grade. The principles of crack sensitivity prediction could apply to other austenitic stainless steel types where chemistry limits are such that ferrite is possible. 
CONTENTS

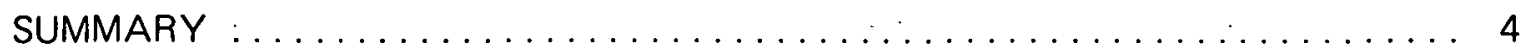

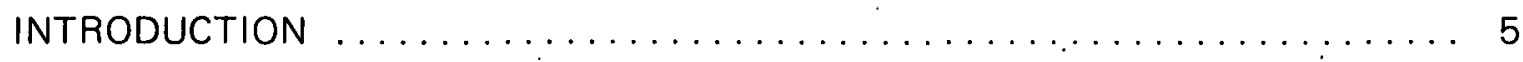

FERRITE AND PHOSPHORUS PLUS SULFUR EFFECTS ON STAINLESS STEEL . . . 8

Experimental Work $\ldots \ldots \ldots \ldots \ldots \ldots \ldots \ldots \ldots \ldots \ldots \ldots$

Procurement of 24 Small Laboratory Heats of Strip ............... 8

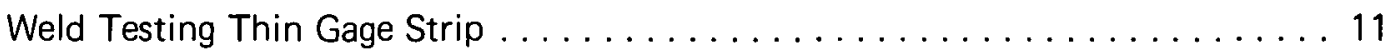

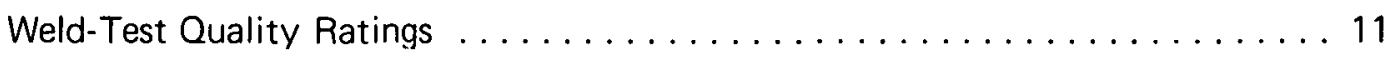

Inaccuracies in Measuring the Ferrite Numbers on Thin Material ......... 13

Chemical Specification for Autogenous Welding Type $309 \ldots \ldots \ldots \ldots 13$

Conclusions and Recommendations .......................... 13

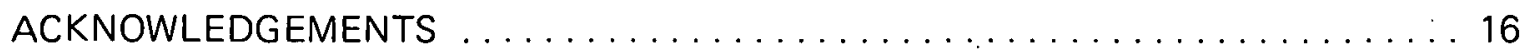

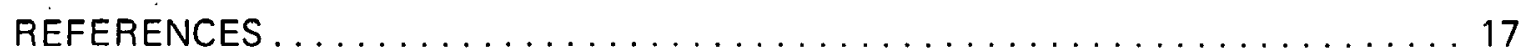




\section{SUMMAR̈Y}

Some commercial heats of Type 309 stainless steel exhibit some degree of cracking 'when welded without the use of filler metal. In contrast, filler metals contain sufficient ferrite so that cracking caused by phosphorus and sulfur is essentially nonexistent. An investigation utilizing 24 laboratory heats has shown that:

1. Crack-free autogenous welds can be made in thin sheets of Type 309 stainless steel if sufficient amounts of ferrite are present in the weld metal, and the necessary amount of ferrite is dependent upon the sum of the amount of phosphorus and sulfur present.

2. Ferrite content, as determined by the Schaeffler diagram, relates to the sum of the phosphorus and sulfur contents. A chart showing this relationship can be used in screening material in stock if the chemistry is known. Material to be welded with filler metal does not need screening. A similar chart can be prepared for ferrite, calculated by methods other than the Schaeffler method.

3. A simple weld test for checking crack susceptibility of thin-gage austenitic stainless steel sheets or strips can be used to check heats.

4. If, when autogenously welded, the weld metal contains $6 \%$ or more delta ferrite, the cracking or fissuring caused by maximum phosphorus and sulfur, as allowed by the AISI specifications, is nullified.

5. A specification for Type 309 stainless steel to be autogenously welded can be prepared which will have from 2 to $11 \%$ ferrite.in the weld. Austenite-forming and ferrite-forming elements can be varied, provided the ferrite limits are maintained. 


\section{INTRODUCTION}

Fabricators, including the Oak Ridge Y-12 Plant, (a) have experienced cracking in some heats of Type 309 stainless steel when doing autogenous welding. This problem was encountered recently in Y-12 when welding a heat of thin-gage stainless steel strip of Type 309. An examination of the chemistry (reported in Table 1) showed the strip to be well within the AISI specification. The ferrite in the weld, as calculated from Schaeffler's diagram(1) (Figure 1), was 3\%; however, the microstructure showed less than $3 \%$. An investigation was conducted to establish a specification for "weldable" Type 309 stainless steel.

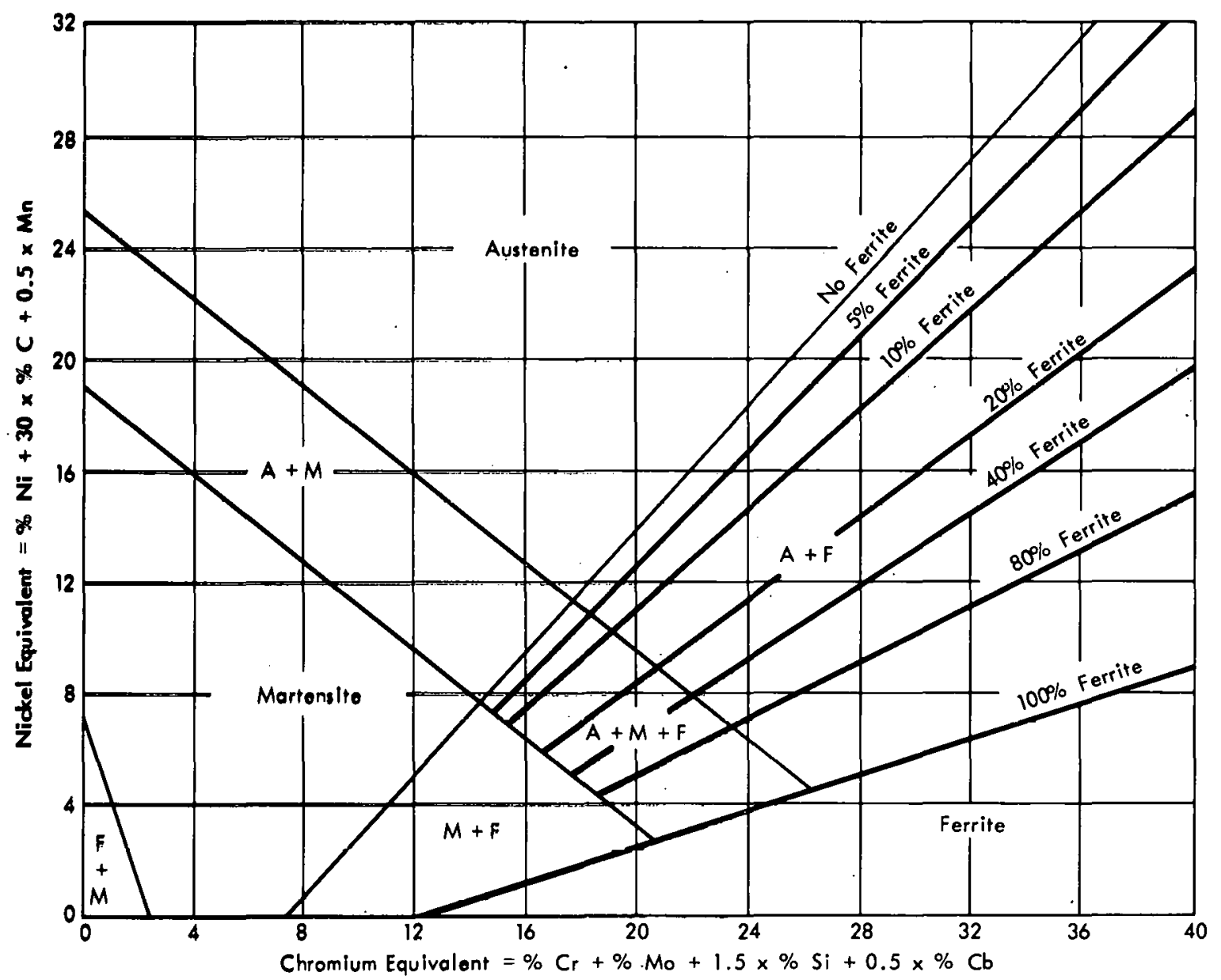

Figure 1. SCHAEFFLER CONSTITUTION DIAGRAM FOR STAINLESS STEEL WELD METAL. (From Technical Report of Teledyne McKoy)

(a) Operated by the Union Carbide Corporation's Nuclear Division for the US Energy Research and Development Administration. 
Table 1

CHE VISTRY OF A CRACK-SENSITIVE HEAT

(All Values in Percent)

\begin{tabular}{|c|c|c|c|c|c|c|c|c|c|c|c|}
\hline & Carbon & Manganese & Phosphorus & Sulfur & Silison & Chromium & Nickel & Molybdenum & Copper & Cobalt & Nitrogen \\
\hline Heat & & & & & & & & & & & \\
\hline $\begin{array}{l}334511 \\
\text { AISI }\end{array}$ & 0.056 & 1.50 & 0.025 & 0.025 & 0.44 & 22.60 & 14.36 & 0.28 & 0.17 & 0.20 & 0.056 \\
\hline Specification & $0.20(\max )$ & $1.0 \cdot 2.00$ & 0.04 & 0.03 & $1.00(\max )$ & $22.00-24.00$ & $12.00-15.00$ & - & - & - & - \\
\hline
\end{tabular}


Much has been published in the literature concerning the effect of phosphorus and sulfur on the cracking of welds and the beneficial effects of ferrite in austenitic welds. (2-4) In a recent article, Campbell (4) pointed out that Type 309 usually has 23\% chromium and $14 \%$ nickel, giving a fully austenitic structure. When the AISI 309 limits are plotted on the Schaeffler diagram, (8) about $50 \%$ of the chemistry range $(5)$ extends into the fully austenitic area (see Figure 2). Much of the Type 309 is produced with a fully austenitic structure to avoid hot tearing during working because of

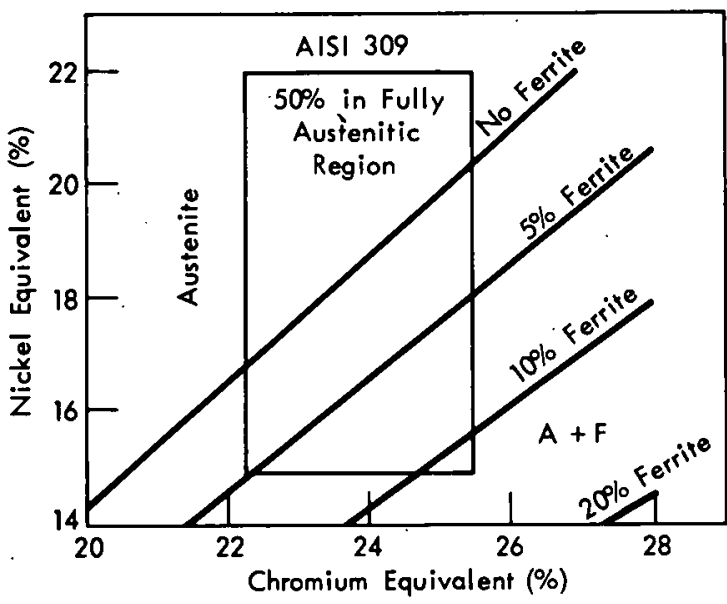

Figure 2. PORTION OF THE SCHAEFFLER DIAGRAM, SHOWING THE BOUNDARY OF AISI 309. (8) the difference in plasticity between the soft ferrite and the tough austenite. (6)

An inquiry was sent to suppliers as to the availability of heats of Type 309 that could be converted into 0.25 -mm-thick strip. The purpose of the request was to select a heat that had less than $14 \%$ nickel and at least $23.2 \%$ chromium. Analyses of 18 heats were submitted. Only one heat made the chromium target, while the nickel exceeded $14 \%$. The results of this experimental work show that 6 of the 18 heats would have been acceptable.

Previous work on several small laboratory heats of Type 309 stainless steel, containing various amounts of delta ferrite and phosphorus plus sulfur, were tested by a weldability test developed at $Y$-12. A relationship appeared to emerge, suggesting that a ratio existed between the delta ferrite and the sum of phosphorus and sulfur present in the weld metal. Failure to meet the ratio was largely responsible for the degree of cracking or microfissuring that could be expected. A continuation of this previous exploratory work was initiated by weld testing 24 laboratory heats of Type 309 stainless steel strip. 


\section{FERRITE AND PHOSPHORUS PLUS SULFUR EFFECTS ON STAINLESS STEEL}

\section{EXPERIMENTAL WORK}

\section{Procurement of 24 Small Laboratory Heats of Strip}

To establish the apparent relationship of the ratio of the sum of the phosphorus and sulfur to the delta ferrite present in the weld metal with respect to incidence of cracking or microfissuring, a total of 24 heats (weighing $1.8 \mathrm{~kg}$ ) of Type 309 were chosen to give the desired phosphorus and sulfur contents with appropriate amounts of delta ferrite. The 24 heats were chosen with three different levels of delta ferrite: 2,7 , and $10 \%$. For each level of ferrite, eight different phosphorus-plus-sulfur values were attempted or chosen. The procedure for making these small heats and rolling to a $0.25-\mathrm{mm}$ strip was worked out with P. T. Lovejoy of the Research Center of Allegheny Ludlum Steel Corporation. The procedure suggested was included in the purchase order and is given in part as:

Supply 24 heats of Type 309 stainless steel strip produced as outlined below:

1. Melt two 22.7-kg vacuum-induction-melt (VIM) heats to the following composition:

$\begin{array}{ccccc}\begin{array}{c}\text { Chromium } \\ (\%)\end{array} & \begin{array}{c}\text { Nickel } \\ (\%)\end{array} & \begin{array}{c}\text { Manganese } \\ (\%)\end{array} & \begin{array}{c}\text { Silicon } \\ (\%)\end{array} & \begin{array}{c}\text { Carbon } \\ (\%)\end{array} \\ & \frac{1 \%}{14.5} & \frac{1.5}{0.75} & \frac{0.03}{22}\end{array}$

All other elements to be kept low through use of electrolytic raw materials for charge.

2. Each $22.7-\mathrm{kg}$ heat will be poured into three ingots of approximately $7.7-\mathrm{kg}$ each. The three ingots from one $22.7-\mathrm{kg}$ heat will be utilized for the phosphorus and sulfur combinations shown below in Groups 1 2, and 3 with one $7.7-\mathrm{kg}$ heat at 22\% chromium ( $2 \%$ ferrite), another $7.7-\mathrm{kg}$ ingot getting an addition of $1.7 \%$ chromium, giving a total of $23.7 \%$ chromium (7\% ferrite), and the third $7.7-\mathrm{kg}$ ingot gettlng an addition of $3 \%$ chromium giving a total of $25 \%$ chromium ( $10 \%$ ferrite).

The three $7.7-\mathrm{kg}$ ingots from the other $27.7-\mathrm{kg}$ melt will have the same chromium additions made to yield ingots of $22 \%, 23.7 \%$, and $25 \%$ chromium. The three ingots will be used for the phosphorus and sulfur combinations shown as Groups 4, 5, and 6.

3. Each $7.7-\mathrm{kg}$ heat will be vacuum induction melted again and divided into four $1.8-\mathrm{kg}$ heats making additions of phosphorus and sulfur according to the table below. Each heat will be identified according to the table below. The first numeral will represent the ferrite content; i.e., 2, 7, or 10, and the next two numerals will represent two of the three digits of phosphorus and sulfur total. 


\begin{tabular}{|c|c|c|c|c|c|c|}
\hline $\begin{array}{c}\text { Group } \\
\text { No. }\end{array}$ & $\begin{array}{l}\text { Heat } \\
\text { No. }\end{array}$ & $\begin{array}{l}\text { Ferrite } \\
(\%)\end{array}$ & $\begin{array}{c}\text { Chromium } \\
(\%)\end{array}$ & $\begin{array}{c}\text { Phosphorus } \\
\text { (\%) }\end{array}$ & $\begin{array}{l}\text { Sulfur } \\
(\%)\end{array}$ & $\begin{array}{l}\text { Phosphorus } \\
\text { Plus } \\
\text { Sulfur } \\
(\%)\end{array}$ \\
\hline \multirow[t]{4}{*}{1} & 215 & $2-3$ & 22 & 0.010 & 0.005 & 0.015 \\
\hline & 220 & $2 \cdot 3$ & 22 & 0.010 & 0.010 & 0.020 \\
\hline & 225 & $2-3$ & 22 & 0.015 & 0.010 & 0.025 \\
\hline & 230 & $2-3$ & 22 & 0.015 & 0.015 & 0.030 \\
\hline \multirow[t]{4}{*}{2} & 725 & 7 & 23.7 & 0.015 & 0.010 & 0.025 \\
\hline & 735 & 7 & 23.7 & 0.015 & 0.020 & 0.035 \\
\hline & 745 & 7 & 23.7 & 0.025 & 0.020 & 0.045 \\
\hline & 755 & 7 & 23.7 & 0.025 & 0.030 & 0.055 \\
\hline \multirow[t]{4}{*}{3} & 1035 & 10 & 25 & 0.020 & 0.015 & 0.035 \\
\hline & 1045 & 10 & 25 & 0.020 & 0.025 & 0.045 \\
\hline & 1055 & 10 & 25 & 0.030 & 0.025 & 0.055 \\
\hline & 1065 & 10 & 25 & 0.030 & 0.035 & 0.065 \\
\hline \multirow[t]{4}{*}{4} & 250 & $2-3$ & 22 & 0.025 & 0.025 & 0.050 \\
\hline & 260 & $2-3$ & 22 & 0.025 & 0.035 & 0.060 \\
\hline & 270 & $2-3$ & 22 & 0.035 & 0.035 & 0.070 \\
\hline & 280 & $2 \cdot 3$ & 22 & 0.035 & 0.045 & 0.080 \\
\hline \multirow[t]{4}{*}{5} & 780 & 7 & 23.7 & 0.030 & 0.050 & 0.080 \\
\hline & 790 & 7 & 23.7 & 0.040 & 0.050 & 0.090 \\
\hline & 710 & 7 & 23.7 & 0.040 & 0.060 & 0.100 \\
\hline & 711 & 7 & 23.7 & 0.050 & 0.060 & 0.110 \\
\hline \multirow[t]{4}{*}{6} & 1010 & 10 & 25 & 0.050 & 0.050 & 0.100 \\
\hline & 1011 & 10 & 25 & 0.050 & 0.060 & 0.110 \\
\hline & 1012 & 10 & 25 & 0.060 & 0.060 & 0.120 \\
\hline & 1013 & 10 & 25 & 0.060 & 0.070 & 0.130 \\
\hline
\end{tabular}

A total of 66 elements will be chemically analyzed on each of the 24 heats. In addition, a nitrogen and oxygen analysis will be made at the beginning and end of pour on each $22.7-\mathrm{kg}$ melt totaling 4 nitrogen and 4 oxygen analyzes.

The 24 ingots will then be hot worked to sheet bar, annealed, conditioned and cold reduced to a final size of approximately $0.25 \mathrm{~mm} \times 152 \mathrm{~mm} \times 914 \mathrm{~mm}$. This product will be annealed and pickled. The amount of product will vary with the conditioning necessary to produce a good surface.

Chemical analysis of the 24 heats and the calculated ferrite and actual phosphorus and sulfur totals are reported in Table 2. 
Table 2

CHEMICAL ANALYSIS OF SPLIT TEST HEATS

(Feırite Centent, Phosphorus Plus Sulfur, Crack Rating'

\begin{tabular}{|c|c|c|c|c|c|c|c|c|c|c|c|c|}
\hline \multirow{2}{*}{$\begin{array}{c}\text { Group } \\
\text { Number }(1)\end{array}$} & \multirow{2}{*}{$\begin{array}{c}\text { Heat } \\
\text { Number }\end{array}$} & \multicolumn{10}{|c|}{. Element $(\%)$} & \multirow[b]{2}{*}{ Crack Ratings ${ }^{(3)}$} \\
\hline & & Carbon & Manganese & Phosphonus & Sulfur & Silicon & Chromium & Niakel & Nitrogen & Ferrite (2) & P Plus S & \\
\hline \multirow[t]{4}{*}{1} & 215 & 0.043 & 1.75 & 0.010 & 0.005 & 0.70 & 22.16 & 14.04 & & 2.5 & 0.015 & 1.1 \\
\hline & 220 & 0.043 & 1.74 & 0.015 & 0.010 & 0.70 & 21.98 & 14.32 & & 2.5 & 0.025 & 1,1 \\
\hline & 225 & 0.041 & 1.74 & 10.016 & 0.010 & 0.72 & 21.88 & 14.28 & & 2.5 & 0.026 & 1,2 \\
\hline & 230 & 0.040 & 1.74 & 0.021 & 0.015 & 0.71 & 21.88 & 14.28 & 0.0058 & 2.5 & 0.036 & 2,2 \\
\hline \multirow[t]{4}{*}{4} & 250 & 0.051 & 1.58 & 0.025 & 0.024 & 0.71 & 22.07 & $14 \cdot 7$ & & 1.5 & 0.049 & 4,4 \\
\hline & 200 & 0.057 & 1.58 & 10.020 & 0.032 & 0.73 & 22.08 & 1430 & & 1.5 & 0.054 & 4,3 \\
\hline & 270 & 0.059 & 1.61 & 0.036 & 0.033 & 0.70 & 21.89 & 1455 & 0.0057 & 1.5 & 0.071 & 4,4 \\
\hline & 280 & 0.060 & 1.60 & 0.004 & 0.039 & 0.70 & 21.93 & $14 \cdot 6$ & & 1.5 & 0.073 & 4,4 \\
\hline \multirow[t]{4}{*}{2} & 725 & 0.054 & 1.55 & 0.015 & 0.009 & 0.71 & 23.98 & 1403 & & 7 & 0.024 & 1,1 \\
\hline & 735 & 0.048 & 1.56 & 0.015 & 0.018 & 0.72 & 23.68 & $14: 6$ & & 7 & 0.033 & 1,1 \\
\hline & 745 & 0.051 & 1.52 & 0.021 & 0.018 & 0.74 & 23.64 & 1433 & & 7 & 0.039 & 1,1 \\
\hline & 755 & 0.050 & 1.54 & 0.028 & 0.024 & 0.73 & 23.78 & 1422 & & 7 & 0.052 & 1,1 \\
\hline \multirow[t]{4}{*}{5} & 780 & 0.054 & 1.53 & 0.030 & 0.043 & 0.72 & 23.88 & 14 i3 & & 5.5 & 0.073 & 1,1 \\
\hline & 790 & 0.06 .1 & 1.60 & 0.034 & 0.045 & 0.71 & 23.53 & 1429 & & 5.5 & 0.079 & 3,2 \\
\hline & 710 & 0.074 & 1.60 & 0.031 & 0.052 & 0.71 & 23.58 & 1.436 & 0.0062 & 5.5 & 0.083 & 3,3 \\
\hline & 711 & 0.063 & 1.59 & $0.0 \leqslant 7$ & 0.053 & 0.71 & 23.58 & 14.31 & & 5.7 & 0.090 & 3,2 \\
\hline \multirow[t]{4}{*}{3} & 1035 & 0.049 & 1.58 & 0.020 & 0.015 & 0.71 & 25.14 & 1409 & & 8.5 & 0.035 & $\begin{array}{l}0,2 \\
1,1\end{array}$ \\
\hline & 1045 & 0.045 & 1.62 & 0.021 & 0.024 & 0.70 & 24.88 & 14.18 & & 8.5 & 0.045 & $\cdot 1,1$ \\
\hline & 1055 & 0.067 & 1.63 & $0.0 \Xi 5$ & 0.024 & 0.71 & 24.96 & 1419 & & 8.5 & 0.059 & 1,1 \\
\hline & 1065 & 0.050 & 1.60 & $0.0 \Xi 0$ & 0.030 & 0.71 & 24.88 & 14.16 & 0.0063 & 8.5 & 0.060 & 1,1 \\
\hline \multirow[t]{6}{*}{6} & 1010 & 0.049 & 1.56 & 0.048 & 0.044 & 0.73 & 25.14 & 1400 & & 8 & 0.092 & 1,1 \\
\hline & 1011 & 0.050 & 1.60 & 0.044 & 0.053 & 0.73 & 24.76 & 14.33 & & 8 & 0.097 & 1,1 \\
\hline & 1012 & 0.068 & 1.67 & 0.058 & 0.054 & 0.72 & 24.60 & $14<8$ & & 8 & 0.122 & 1,1 \\
\hline & 1013 & 0.061 & 1.60 & 0.051 & 0.052 & 0.71 & 24.72 & $14: 29$ & 0.0061 & 8 & 0.103 & 1,2 \\
\hline & Standard $(4) 304 \mathrm{~L}$ & 0.019 & 1.53 & 0.018 & 0.014 & 0.52 & 18.64 & 9.27 & & 8 & 0.032 & 1,1 \\
\hline & $\operatorname{cs}^{(5)} 309$ & 0.056 & 1.50 & 0.025 & 0.025 & 0.44 & 22.60 & $14 \approx 6$ & 0.056 & 3 & 0.050 & . 4,4 \\
\hline
\end{tabular}

(1) Nitrogen and Oxygen on the Two Master Heats Covering Groups 1,2,3 and 4,5,6:

(2) Calculated ferrite from the Schaeffler diagram.

$$
N(\%) \quad O(\%)
$$

Groups 1,2,3 $0.0029 \quad 0.0126$

0.00350 .0148

\begin{tabular}{lll} 
Groups 4,5,6 $\quad 0.0029 \quad 0.0138$ \\
\hline
\end{tabular}

$0.0027 \quad 0.0142$

(3) Crack ratings (two numbers represent a test panel). 1 - No cracks.
2 - No more than two cracks.
3 - More than two cracks.

3 - More than two cracks.
4 - Light seam through cracks.

(4) Standard 304L (Heat 102001).

(5) Crack sensitive (Heat 334511). For this test, there was also a molybdenum content of $0.28 \%$. 
All $1.8-\mathrm{kg}$ ingots were processed in the laboratory to strips that were $0.25 \mathrm{~mm}$ thick by $100 \mathrm{~mm}$ wide by approximately $1220 \mathrm{~mm}$ long. These strips were annealed at $1008^{\circ} \mathrm{C}$, air cooled, pickled, and finished with a light cold-roll pass.

\section{Weld Testing Thin-Gage Strip}

Strips, $100 \mathrm{~mm}$ wide by $200 \mathrm{~mm}$ long, were welded to a standard Type 304L stainless steel of equal size, producing a weld test specimen $400 \mathrm{~mm}$ long by $100 \mathrm{~mm}$ wide by $0.25 \mathrm{~mm}$ thick. (Length and width can be varied to suit the material size available.) Only 0.25-mm-thick strip has been used for this test. Other thicknesses will need similar evaluation.

The test was performed by making a series of fusion passes side by side along the length of the combined standard and test-specimen strips. Twelve to 16 passes were usually made unless the test piece proved to be very crack sensitive, in which case the test was terminated early. The test was performed twice on each test panel. A sketch of a completed test panel is given in Figure 3. Forty-eight test panels were welded on the 24 heats.

All weld tests were performed with a Vickers Model 50 power supply, using straight polarity and a negative electrode. An Airline seam welder with 0.92-m copper bars held the sample

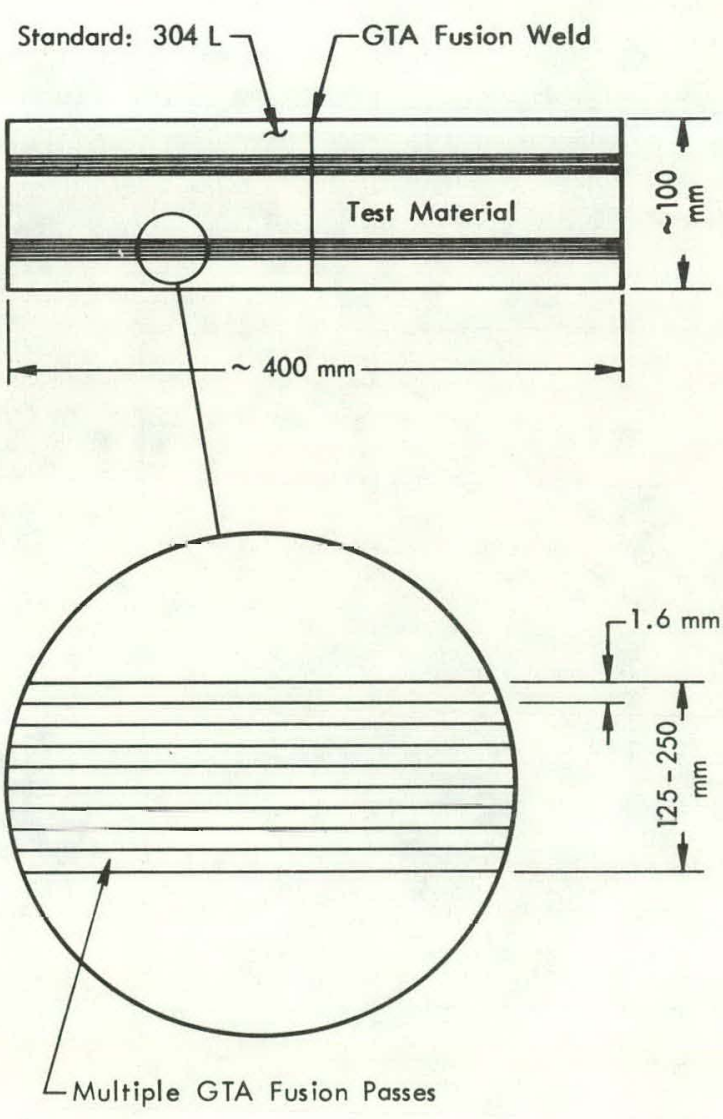

Figuie 3. WLLD-CRACK SENSITIVITY TEST. over a copper backup bar having a groove $1.5 \mathrm{~mm}$ wide by $0.8 \mathrm{~mm}$ deep. Weld parameters were: 30 amperes, 8 volts, a $610-\mathrm{mm} / \mathrm{min}$ travel speed and an argon flow of $14.1 \mathrm{~m}^{3} / \mathrm{hr}$.

\section{Weld-Test Quality Ratings}

If the test specimen showed no visible cracks, the back side of the weld was painted with dye penetrant and the top side with the developer. This procedure for liquid-penetrant testing of thin sheet is more reliable than the standard method of putting dye and developer on the same side. In some tests using the standard procedure, the cleaner was found to remove the dye completely from the crack.

A qualitative rating was established for this series of tests with ratings as follows: (1) no cracks present, (2) not more than two cracks, (3) more than two cracks, and (4) the dye check was not reeded since it was possible to see through the cracks. A photograph of one series of weld passes on an early test is given in Figure 4 . The size of 
the test panel was larger. Cracking was so severe that penetrant testing was not necessary. Nevertheless, the penetrant test was made to make the cracks easily visible in the photograph.

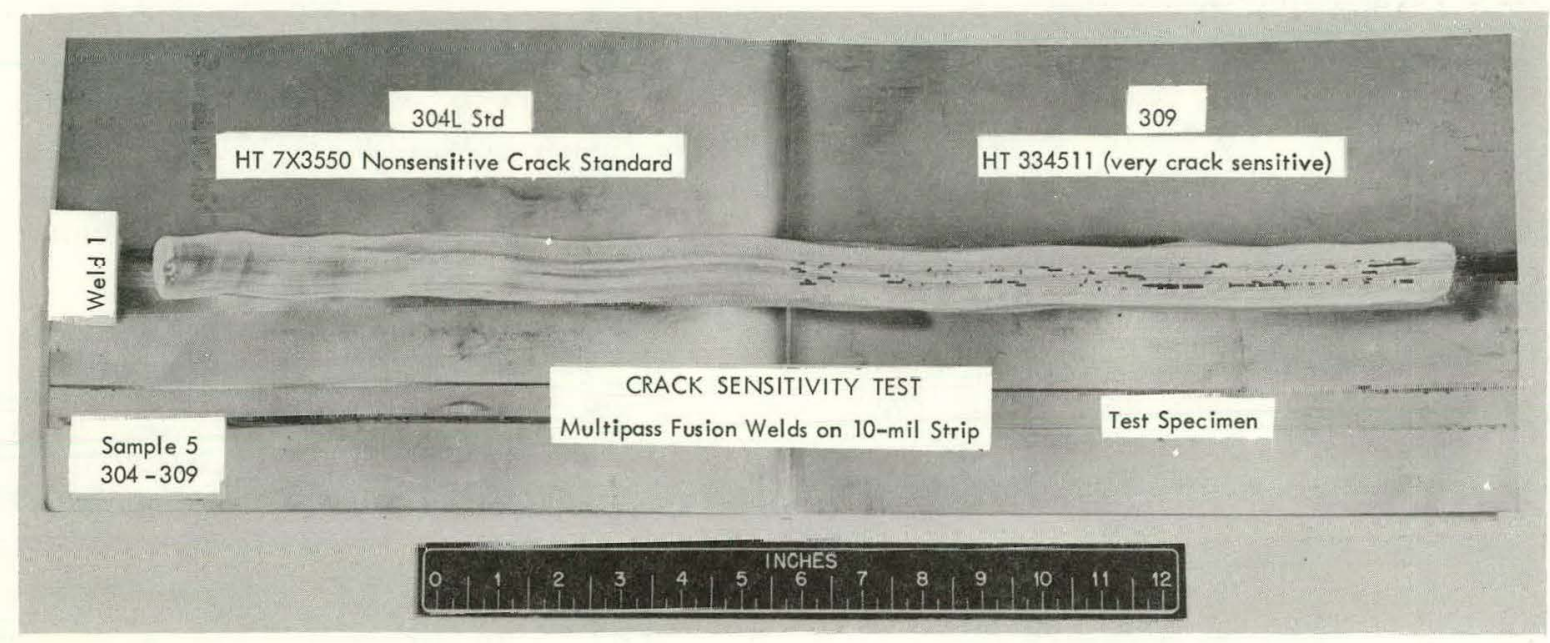

Figure 4. CRACK SENSITIVITY TEST.

144383

The results of these tests are shown by the plot of Figure 5. A region is drawn which separates the crack-free composition from the cracking composition. The slope of the region shows that for each change of $0.014 \%$ in phosphorus plus sulfur, an increase in ferrite of $1 \%$ is necded. The region intercepts the zero-ferrite ordinate at a low phosphorıs-plı.ıs-sulfur valuc. The standard Type 304 material and crack-sensitive commercial Type 309, which are

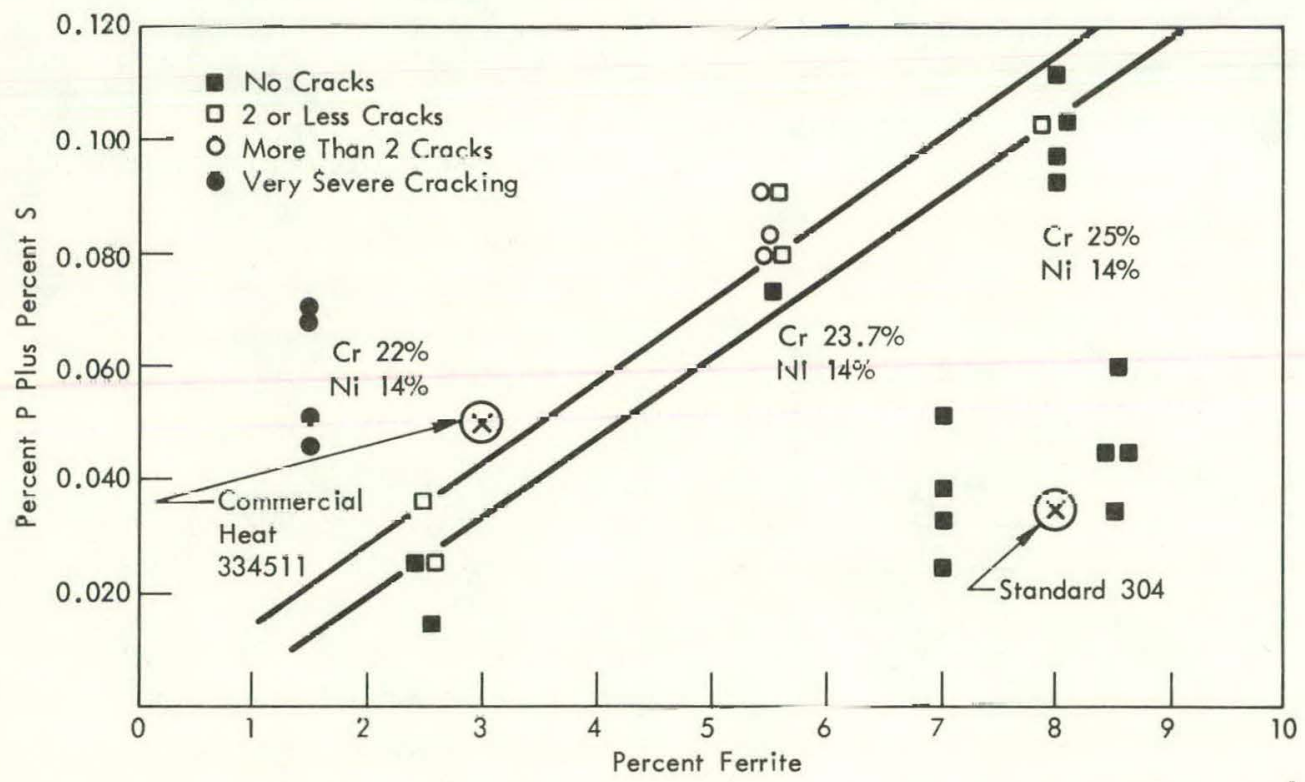

Figure 5. PERCENT PHOSPHORUS PLUS PERCENT SULFUR AS A FUNCTION OF THE PERCENT FERRITE. (A Crack Susceptibility Chart) 
also reported in Table 2, have a ferrite content of 8 and 3\% and a phosphorus-plus-sulfur sum of 0.032 and $0.050 \%$, respectively These values are also noted in Figure 5.

\section{Inaccuracies in Measuring the Ferrite Numbers on Thin Material}

The ferrite numbers or ferrite percent were measured on all of the welds and found to be considerably below the calculated percent. The technique used in measuring was in accordance to the method established by the Welding Research Council (WRC). (7)

Thorvaldson(8) of the Dow-Rocky Flats Plant conducted an investigation into the minimum thickness of stainless steel weld that can be measured in accordance to the WRC procedure. His study showed the minimum thickness that can be measured is $2.5 \mathrm{~mm}$. Below this thickness, ferrite numbers decrease with decreasing thickness.

\section{Chemical Specification for Autogenous Welding Type 309}

In developing a specification for commercial Type 309 sheet suitable for :autogenous welding, it is proposed to further restrict the nickel, chromium, carbon phosphorus, and sulfur, as presently specified in AISI Type 309. Table 3 shows the limits for autogenous weldable Type 309 (aw 309). These limits give a minimum and maximum ferrite between 2 to $11 \%$; the average will be $5-6 \%$. The proposed chemistry can be changed by altering the austenite and ferrite formers to give the same range of ferrite. Phosphorus and sulfur contents should not exceed the sum of $0.035 \%$. The specification limits are now superimposed on Schaeffler's diagram in Figure 6 with the AISI 309 limits and welding rod specification limits of ER 309. (5) The more restrictive chemistry is clearly illustrated.

Table 3

CHEMICAL SPECIFICATION FOR AUTOGENOUS WELDING TYPE 309

\begin{tabular}{ccccccc}
\hline \multicolumn{9}{c}{$\begin{array}{c}\text { Phosphorus } \\
\text { Plus }\end{array}$} \\
$\begin{array}{c}\text { Carbon } \\
(\%)\end{array}$ & $\begin{array}{c}\text { Manganese } \\
(\%)\end{array}$ & $\begin{array}{c}\text { Sulfur } \\
(\%)\end{array}$ & $\begin{array}{c}\text { Silicon } \\
(\%)\end{array}$ & $\begin{array}{c}\text { Chromium } \\
(\%)\end{array}$ & $\begin{array}{c}\text { Nickel } \\
(\%)\end{array}$ & $\begin{array}{c}\text { Nitrogen } \\
(\%)\end{array}$ \\
\hline $0.030-0.060$ & $1.00 \cdot 2.00$ & $0.035(\max )$ & $0.30-0.75$ & $22.50-23.50$ & $13.00-14.00$ & $0.05(\max )$ \\
\hline
\end{tabular}

No attempt has been made to explore industry's acceptance of this specification

\section{CONCLUSIONS AND RECOMMENDATIONS}

A weld test for determining the weldability of thin stainless steel sheet or strip has been described which compares the weldability of an austenitic stainless steel with that of a good, weldable Type 304L stainless steel. The weld test has been used to confirm cracking problems on new heats of material and also to develop confidence in new material which exhibited crack resistance cqual to that of good; weldable $304 \mathrm{~L}$. 


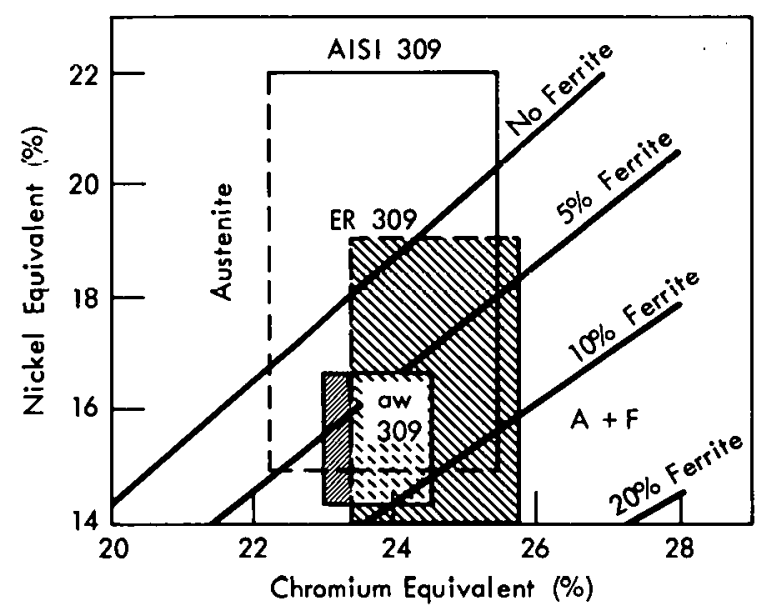

Figure 6. PORTION OF THE SCHAEFFLER DIAGRAM, SHOWING BOUNDARIES OF AISI 309, ER 309, and aw 309.
The chart developed in Figure 5 is reproduced in Figure 7 for use by such groups as shop personnel and purchasing agents when having a choice of heats from which to select to do a job, or to purchase material from a warehouse. Users of the chart must be capable of determining the ferrite from Schaeffler's diagram. Technical people preferring DeLong's or Hull's (9) method of determining ferrite could adapt the chart to suit these methods.

As an example of its use, an examination of 18 heats of Type 309 submitted for possible use for autogenous welding were turned down because of high nickel (above 14\%) and low chromium (below 23.2\%) and were thought to be fully austenitic or very low in ferrite when welded. The 18 heats, when plotted on the crack susceptibility chart, showed that six heats were acceptable, nine heats, or $50 \%$, unacceptable, and three heats questionable. The 18 heats are shown plotted in Figure 8.

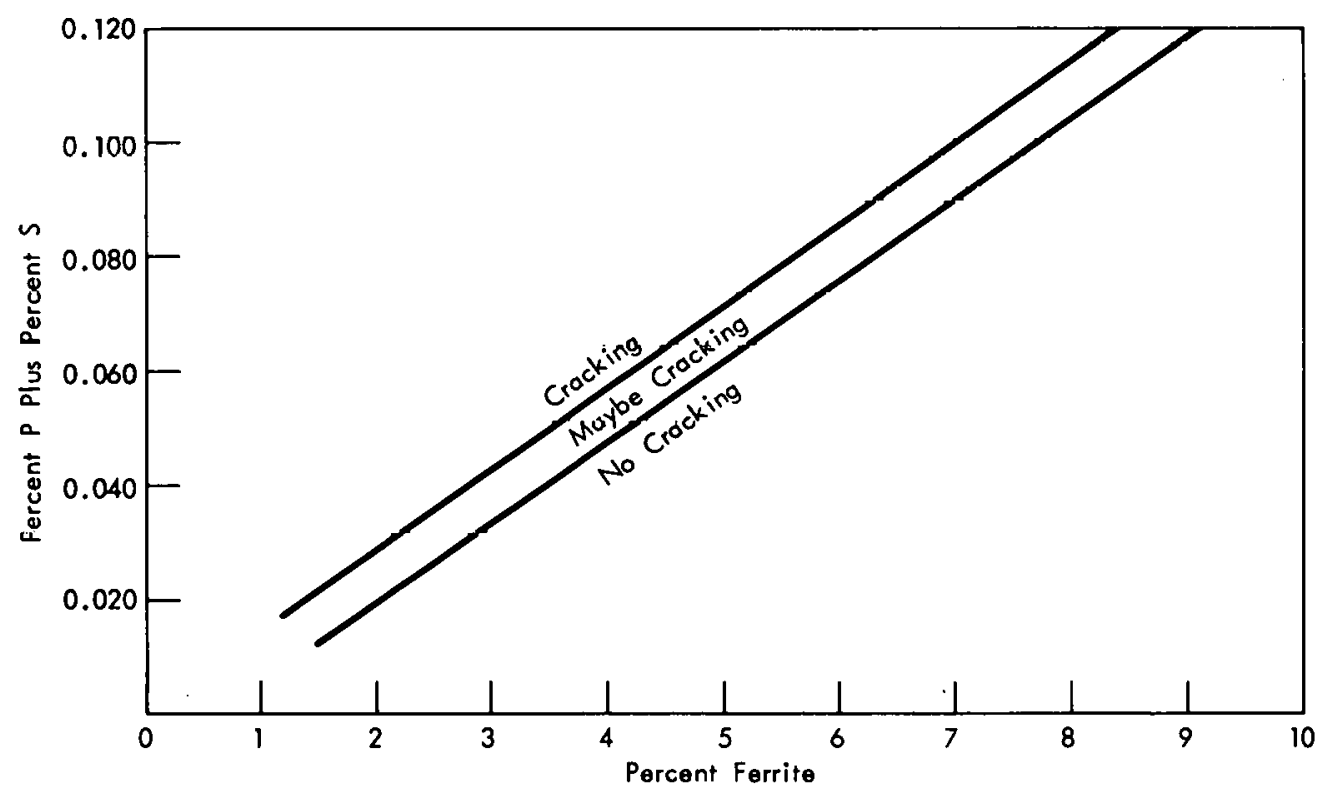

Figure 7. CRACK SUSCEPTIBILITY CHART.

Had DeLong's latest diagram been used instead of the Schaeffler diagram, the chromium equivalents would be the same and the nickel equivalents would be increased by only 0.1 to $0.2 \%$ because of the very low nitrogen content in these laboratory heats. The ferrite percent or ferrite number read from DeLong's diagram would then be as much as $2 \%$, or two numbers higher. 


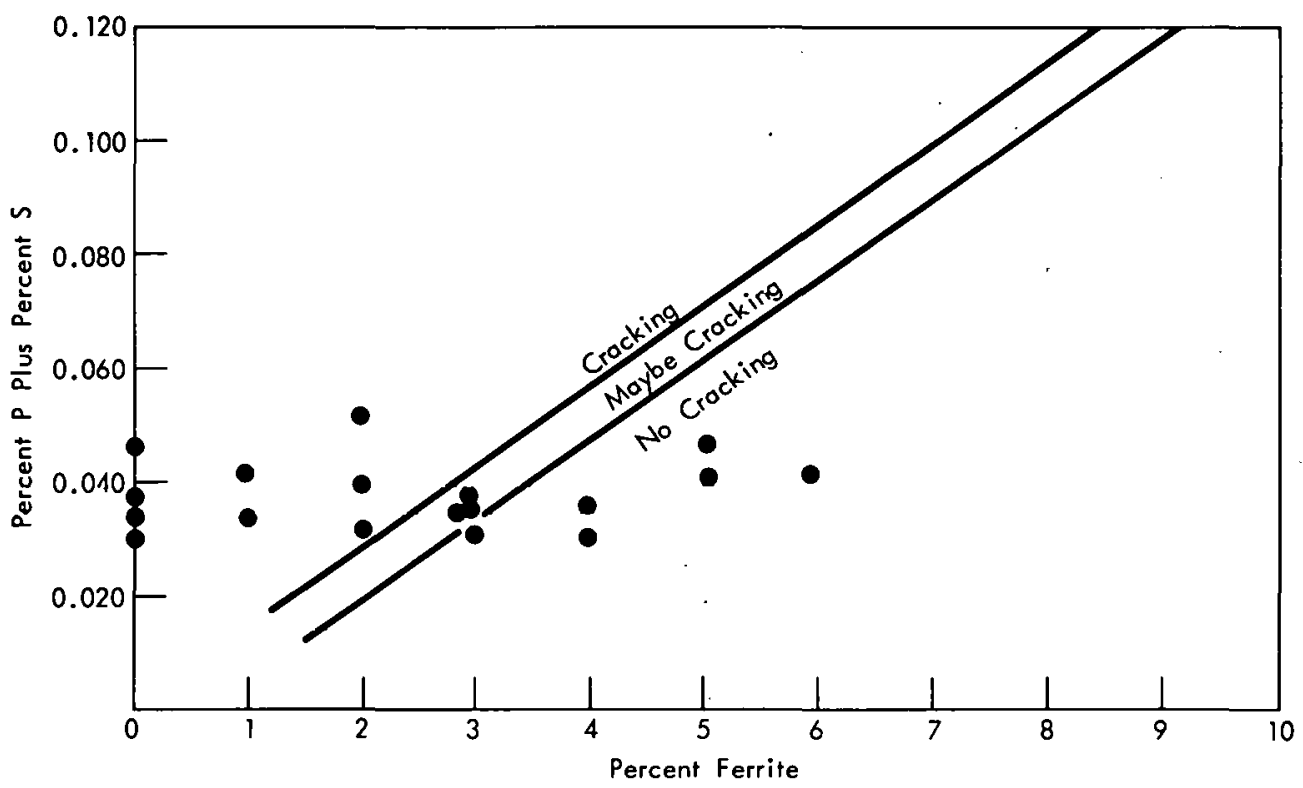

Figure 8. CRACK SUSCEPTIBILITY OF EIGHTEEN COMMERCIAL HEATS.

The ferrite content on Commercial Heat 334511 checks out the same on either Schaeffler's or DeLong's diagram because the nickel equivalent is $1.6 \%$ higher due to the nitrogen factor in DeLong's diagram.

The specification for aw 309 is much more restrictive. The chemistry limits sets by the specification will assure a minimum of $2 \%$ ferrite (Schaeffler diagram) or $3 \%$ (DeLong diagram). Specifying the phosphorus and sulfur as the sum allows the manufacturer more flexibility to meet the lower tolerances on these two elements. Brooks $(10)$ reports that, in high-manganese stainless steels, phosphorus is more detrimental to cracking than sulfur because of the morphology of the phosphides and sulfides. No attempt was made here to determine the potency of the two elements. At this time both are treated equally.

The chemistry limits on the specification for ER 309 would allow some possibility of weld metal with no ferrite; however, since this material is produced for filler metal, it is produced, in practice, with chemistries which result in 6 to $7 \%$ ferrite in the weld metal.

Phosphorus and sulfur are believed to be, as a result of this study, the main culprits in producing cracking in austenitic stainless steel welds. Other elements may reduce the cracking tendency of these two elements, while others may enhance their cracking tendencies. These influences would, in effect, cause a shifting of the lines, in Figure 7, up or down. 


\section{ACKNOWLEDGEMENTS}

Appreciation is expressed to A. B. Townsend for his many valuable contributions during the course of the investigation and, particularly, his suggestion in treating phosphorus and sulfur as a sum from which the crack susceptibility chart was developed. His editing was also very helpful in the preparation of this report. 


\section{REFERENCES}

(1) Schaeffler, A. L.; "Constitution Diagrams for Stainless Steel Weld Metals", Meta/s Progress, 56, pp 680 and 680-B; November 1949.

(2) Rozet, D., Campbell, H.C., and Thomas, R. D., Jr; "Effects of Weld Metal Composition on the Strength and Ductility of 15\% Chromium-35\% Nickel Welds", Welding Journal, p 481-S, Research Supplement; October 1948.

(3) Campbell, H. C. and Thomas, R. D. Jr; "The Effect of Alloying Elements on the Tensile Properties of 25-20 Weld Metal", Welding Journal, 25, (11), pp 760-S - 768-S, Research Supplement; November 1946.

(4) Campbell, H. C.; "The Ferrite Prublem - Is It a Tempest in a Teapot?", Welding Journal, 54, (12), pp 867 - 871; December 1975.

(5) AWS Commitee on Filler Metal; "Stainless Steel Welding Rods and Bare Electrodes", Welding Journal, 33, (5), pp 433 - 437; May 1954.

(6) US Steel Corporation; The Making, Shaping, and Treating of Steel, 7th Edition, p 859.

(7) Long, C. and DeLong, W.; "The Ferrite Content of Austenitic Stainless Steel Weld Metal", Welding Journal, 52, (7), pp 281-S - 297-S, Research Supplement; July 1975.

(8) Thorvaldson, W. G., Dow Chemical Company; "A Proposal to Implement a New Procedure for Delta Ferrite Measurements",.Personal Communication.

(9) Hull, F.; "Delta Ferrite and Martensite Formation in Stainless Steels", Welding Journal, 52, (5), pp 193-S - 203-S, Research Supplement; May 1973.

(10) Brooks, J. A.; "Weldability of High N, High Mn Austenitic Stainless Steel", Welding Journal, 54, (6), pp 189-S - 195-S, Research Supplement; June 1975. 


\section{Distribution}

Energy Research and Development

Administration - Oak Ridge

Hickman, H. D.

Leed, R. E.

Zachry, D. S., Jr

Lawrence Livermore Laboratory

Nelson, W. E.

Robbins, J. L.

Los Alamos Scientific Laboratory

Hoyt, H. C.

Sandstrom, D. J.

Oak Ridge Gaseous Diffusion Plant

Stief, S. S.

Wilcox, W. J., Jr

Oak Ridge National Laboratory

McGuffey, J. R.

Slaunhter, G. M.

Weir, J. R., Jr

\section{Oak Ridge Y-12 Plant}

Alvey, H. E.

Armstrong, R. C.

Bernander, N. K.

Burditt, R. B.

Burkhart, L. E.

Dodson, W. H.

Duggan, $H$. G.

Ebert, T. H.

Ellingson, R. D.

Fraser, R. J.
Gritzner, V. B.

Jackson, V. C.

Jones, F. W.

Kahl, K. G.

Keith, A.

Kite, H. T. (10)

Lambert, F. J. (10)

Mills, J. M., Jr

Phillips, L. R.

Schreyer, J. M.

Smith, H. F., Jr

Smith, R. D.

Stoner, H. H.

Tewes, W. E.

Tlison, F. V.

Townsend, A. B.

Weathersby, W. E.

Williams, R. D.

Yaygi, W. J./Googin J. M.

$Y-12$ Central Files (master copy)

Y.12 Ccntral Filcs (route copy)

$Y-12$ Central Files ( $Y-12 R C)$

$Y-12$ Central Files (5)

Zerby, C. D.

Paducah Gaseous Diffusion Plant

Levin, R. W.

Rockwell International - Rocky Flats

Wiederecht, D. A.

Sandia - Albuquerque

Davis, M. J.

Sandia - Livermore

Adolphson, D. R. 


\section{Union Carbide Corporation-Parma}

Research Center

Chambers, W. E.

\section{University of Tennessee-College}

of Engineering

Stansbury, E. E.

In addition, this report is distributed in accordance with the category UC-25, Materials, as given in the USERDA Standard Distribution Lists for Unclassified Scientific and Technical Reports, TID-4500. 